\title{
Imparting the skills in the young minds- Employability skills and armor to withstand the environmental challenges
}

\author{
M. Rajalakshmi \\ Department of Commerce, Quaid-E-Millath Government College for Women, Chennai, Tamil Nadu, India
}

\begin{abstract}
The economic development of any nation, without equipping the youth with the skills they are supposed to put on, undoubtedly will lose its charm in the progress of lifting up the nation. So called skills are the well knit set of actions to be taken by a young mind hunting for job before finishing the graduation. Honing of employability skills a need of the hour to be proclaimed in the campus of the educational institutions.
\end{abstract}

Key words: Employability skills, Educational Institutions, Corporate sectors, Parents

Aim of the study: The present paper intends to find out the depth of the understanding of the students about the employability skills. In current scenario the exodus of the youth in search of needed skills for better employment has started. Understanding the passion, an unquenchable thirst of becoming someone (whom they have chosen as the role model or to become a good multi skill tasker) to be understood by the stakeholders of the total educational scenario.

Methodology: To find out the opinion of the students regarding their awareness about the employability skills. Totally 50 college students of Chennai comprising of UG and PG were selected and the questionnaires were distributed to them. Random sampling method is used to distribute the questionnaires. Students were asked to fill up the questionnaire after explaining the meaning of each and every question respectively.

\section{.Findings and Discussions}

The questions to be raised, analyzed in the light of the different parameters are:

What are the skills they are supposed to imbibe?

Who has the untimate responsibility in imparting the needed skills?

Where is the premise that serves as a platform? -all these questions will pave the way for fashioning the hearts of young minds and to enthrall them with their amazing ability.

\section{Introduction}

Employability skills are not only needed for initial stage of entry into the job but also to maintain and progress throughout the career, provided these skills are designed in such a way to sense the mood of the job providers. Many employers satisfy themselves by providing training and development by initial skill set. Securing an employment in the present environmental context is not a cakewalk. The basic skill development structure without testing in the light of the environmental factors will pave the way for pigheadedness with which the learners are prepared to pursue it.

\section{Skills to gain employment}

Training in key generic skills (Literacy, Numeracy, customer services oral communication skills organizing etc) will give them a head start into the employment. One to move on in the job, the generic skills are necessary, somewhere subconsciously that will become the stepping stone for further training. The idea of adapting to changes is an important ingredient in the structure of employability skills in modern workplaces, which must take out the thinking of oneself as a finished product. Various types of interview adopted in the Human Resource field alarms a person about the expectation of the job in the labour market.

\section{Skills to maintain employment}

People need to be consistent and careful in crafting the value propositions to make themselves soaring to new heights. Aesthetic skills are inevitable for the individuals to present themselves at work. Mr. Pravin Kumar Rathi, Director Cancri technologies ltd. says in IIPM Alumini magazine CULT-apart from technical skills, logical and analytical skills are paramount in determining the career of any IT person.[1]

Today the corporate world has to accept the fact that the employers are looking for many skills beyond the theories thus the employability skills of course takes up a very hard time in the process of corporate grooming. 


\section{Skill to create employment}

The plethora of information regarding the employability skills are found familiar and sound similar in the context of employment scenario. In the study conducted among the college students they were kindled to answer if they had any vision of becoming an entrepreneur or a key personnel in the organization by which they could provide employment opportunities. The following are the findings from the study- positively there was no negative answer and everyone revealed their inner feeling of becoming job providers instead of job seekers. This syndrome should not left as the leaking pipeline succumbed by the societal factors. This need is to be fuelled further by the infrastructural facilities.

\subsection{Table Showing The Interest Of The Students In Becoming The Entrepreneurs After Their}

\begin{tabular}{|c|c|c|c|c|}
\hline \multicolumn{7}{|c|}{ Graduation } \\
\hline Total No. of Students & Agree & $\begin{array}{c}\text { Somewhat } \\
\text { Agree }\end{array}$ & $\begin{array}{l}\text { Strongly } \\
\text { Agree }\end{array}$ & Disagree \\
\hline $30(\mathrm{UG})$ & 40 & 20 & 40 & nil \\
\hline $20(\mathrm{PG})$ & 35 & 05 & 60 & nil \\
\hline
\end{tabular}

To support this, in the words of Annie Gottlier -"It is hard when I have to and so easy when I want to" and interpret in this manner-"It is hard when they have to become the entrepreneurs and so easy when want to become the entrepreneurs". Let us remember the Chinese proverb "It is better to teach him the technique of fishing instead providing the fish everyday'. So the employability skill makes him to find out his own ways and means to get a job. According to International Commission on Peace \& Food first proposed to the United Nations in 1994 that employment be considered a basic human right to be constitutionally guaranteed, at that time, the proposal appeared visionary and unlikely to be given a serious consideration. Now this proposal has been endorsed by Government of India and it is in the process of converted into law.[2] (Rural employment strategies for India/MSS Research Dt 12/13/12) More and more inventions and new tactics are to be germinated in the Indian soil to perceive this thought.

The society is thankful to the newly emerged entrepreneurs -courier companies, Xerox shops, Internet cafes, Fast food restaurants, Cell Phone shops, Boutiques etc for the last two decades in their contribution to the society in the form of fetching a reasonable share of national income instead of cursing their idleness and praising their talents.

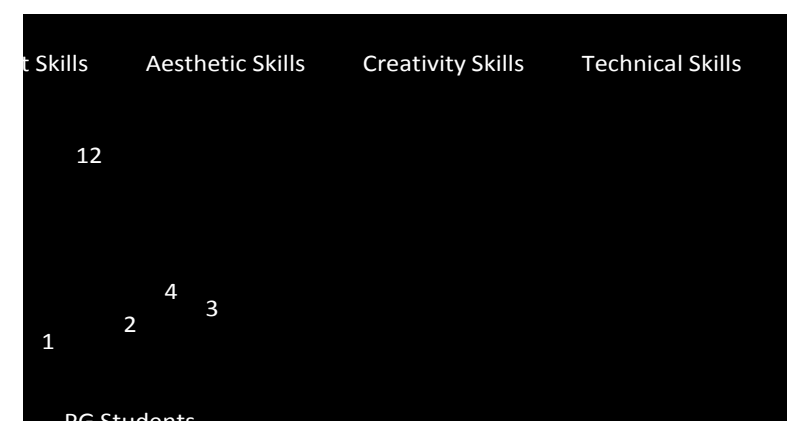

V. Employability skills for sustainable development

Globalization, increased competition and magnificent changes in the corporate level have lifted up the veil named after job for life. Today the employability skills are not only welcomes the youth with its widespread arms, but it is also the youth who runs towards to take the shelter, to secure, to maintain and to make progress in their employment.

Mr. Padam Garg, Ex-CEO Metaflex Doors India ltd in his alumni speech for Smart Manager May-June 2012 makes a mention that the biggest challenge and solution is people- to find, to train, to develop and to retain the people.[3] So the corporate icons have cast their nets and become the fishers of young graduates. The generic skills such as problem solving, customer handling communication and team working skills will undoubtedly make the workforce to hold onto their employment, the wider employability skills -decision making, reasoning out, logical thinking should be embedded to reach out the level of sustainable development. Definitely these skills come out of a person who is cool headed but with hot foot.

If we raise a question-Is any attractive incentive available to the individuals to engage themselves in putting on these skills, the answer would be the passion within oneself. How is this passion obtained? Is it inborn quality or procured from the environmental happenings? Both- it is the combination of both the elements. 


\subsection{The magnitude of the problem-Employability skills, the multitude has the desire to pursue it.}

Fixing the square peg into a square hole-right man for the right job-this mantra forms the root cause for the mountain peak success or the bottom down failures. These are the days where every country looks around to update their technology, and it is high time for every developing nation to gird its garment of resources to march towards the economic development. It is the paramount role of the youth to take part in the man machine interface. The need has arisen for every youth to deepen their talent base, sharpen their skill base and to widen their focus.

The soft skill which amounts to the very basic skills nowadays needs to be whet. But it is quite pathetic that some students lack this very essential skills inspite of the efforts taken by the educational institutions to impart in the minds of the youth. The recent study conducted by the researcher among the college students revealed the following facts. This finding shows that the right amount of dosage (needed employability skills) is not given to the right person (students) at the right time (duration of the course).

\section{$5.2 \%$ OF STUDENTS EXPRESS THEIR OPINION ABOUT THEIR SOFTSKILL DEFICIT}

$\begin{array}{cc}\text { UG Students } & \text { PG Students } \\ 44 \% & 56 \%\end{array}$

\subsection{Who will bell the cat?}

The outcries of the people who are affected directly or sensitively by the most spoken and least understood concept, have to be proclaimed louder, to be heard by the huge mass, and to make it known to the stakeholders:

Ignorant parents - When my son/daughter will get the job?

Unaware Youth - How can I get the job which I am dreaming of? market?

Stereotyped Educational Institutions- Why my graduates are not able to fit in themselves in the job training?

Visionary Management Institutes- Where are my trainers who have the thirst and passion to pursue the

Cosmopolitan Corporate sectors- Which person among these young generation will fulfill my organizational plan?

Money spinning Commercial banks- What will happen to my money if I lend it out to him for his higher studies?

Exploratory Researchers on this topic- Is any other new factor sound strange in this topic?

For the above mentioned queries, the single answer is the employability skills are not the tailor-made solutions for unemployment or the disguised unemployment. It needs 360 degree mentoring to dig out the hidden treasures (youth potential) in the land of India, where many people starve in search of that.

\subsection{Skill gaps}

Skills gaps not always alarms an organization in the realm of employee's efficiency. It may be caused because of the unprepared ness of the employees to acquaint themselves with the changes in the technology or it may be the deficiency that has come along with an new entrant in an organization. These skills gaps could be very well bridged up by giving training and more experience and it is transitional in nature. The skills gaps which have arisen due to the inefficiency of the employees have to be dealt seriously and this conceptual complexity in discriminating the transitional skills gaps and the real skill deficit will have to be justified in the course of time.

5.4.1 \% OF STUDENTS WHO ADMITS THEY MIGHT LACK THE EMPLOYABILITY SKILLS

\begin{tabular}{|c|c|c|c|c|}
\hline $\begin{array}{l}\text { Total No. of } \\
\text { Students }\end{array}$ & Agree & $\begin{array}{l}\text { Somewhat } \\
\text { Agree }\end{array}$ & $\begin{array}{l}\text { Strongly } \\
\text { Agree }\end{array}$ & Disagree \\
\hline $30(\mathrm{UG})$ & 40 & 27 & 27 & 6 \\
\hline $20(\mathrm{PG})$ & 70 & 30 & nil & nil \\
\hline
\end{tabular}


The above tabulated information clearly reveals that majority of the students expresses their opinion regarding their skills deficit. The confidence is revealed out only by $6 \%$. The Post graduate students though none of them expressing it strongly, but all of them expresses they have the approval regarding the deficit and no one disagree it.

The real skill gaps disguise itself in the cloak of the transitory skill and eats up the training cost and time. While we draw up the demarcation line between the transitory skills and the real skill gaps, it is necessary to deepen the expectation within the horizons of the management instead of broadening out. Because there may be the people who lack the skills (though it will not provide everything in the area where he is employed- but it is expected by the employer ) but possess the skills (though it will provide something in the area where he is employed- but it is not expected by the employer.)

When these two sets of equations are formed to solve a single problem i.e imparting the needed skills, both the aspects confers the same meaning. It is only the grit and the determination of the employer in imparting. Other words management must have the plethora of information which are inevitable to explore the human resources which are unreached and untouched.

Employers of the present world need to understand the Human Resources in the organization to be considered with humanitarian approach especially, the young minds who enters into the organization with the dreams of fulfilling their parents ambitions, meeting the financial obligations and upbringing their family status which is also a nuclear concept for the economic development as a whole.

C.B. Gupta in his book 'Modern Business Management' superbly describes that the interview method adopted to select a employee must create a rapport between the employer and the candidate'. Likewise the interview must be to interweave the ideas of the employer and the employee, where the employer tactfully analyses the hidden potentialities and not only out seen talents, both are the essential elements in bridging the fancy concept uttered by many as skills gaps.

Here a note of caution is needed while drawing out the conclusion about the skills gaps. Since the concept (skills) had germinated, it has been frequently associated with the lower level cadres of organization. As for as concerned with the employability skills, the total workforce is categorized as the human capital- its acquisition and sustainability cannot be filled up completely by any other factors of production. The real essence of it to be emphasized not only in the realm of blue collars but need to be proclaimed also in the upper echelons of management.

\subsection{User Engagement concept}

The management must have the awareness of creating user engagement concept through their way of approach, training and molding up their employees for the required task. The user engagement concept is sensed out in most of the sales promotion techniques. For e.g. Tequila drinks comes out with this saying 'tequila is a case where the product is bitter and the flavor is less balanced, but still the ritual brings out satisfying experience. Likewise it should be the strategy of the corporate world to make the bitter product to turn into a better product by their association with the organization.

After hearkening to the views of the students and also referring the various research and made in this area. The researcher brings forth the following suggestions in order to be embedded in the reforms which encompass the concept employability skills.

\section{Parental role of an educational institution}

Let us take this issue by placing a query i.e How many of the parents of the present unemployed youth are aware of the present employment opportunities? . If we ask this question to the parents of the newly crowned graduates. There would not be at least $25 \%$ of the total to come out with the positive answers. So now it is the main responsibility of the educational institutions to convert the raw materials like students to be the finished products(who would be procured as the hotcakes by the employers)

Amanda Benjamin ,University of New Brunswick -Turning Eastside kids into Westside kids: Employability Skills in the British Columbia Career and Personal Planning Curriculum, the author concludes the research with the saying "Discussion of the labor market need to be more central in career education classroom so that the students can have a better understanding of the reality of work in this society".[4]

The students should be exposed to the multi-various skills intensively. Though we cannot expect the 360 mentoring, it is the need of the hour for the educational institutions especially the teachers and the professors to make the students hearts and minds flexible to turn around and look into the various opportunities awaits for them.

First of all the psychology of the students to be diverted towards the skills to be put on. To exercise this, sowing of the seeds of becoming an entrepreneur, chief executive or any desired role, which will certainly create a positive effect. 
Creating the employment awareness should be designed in the academic curriculum like any other virtual subjects like yoga, meditation etc. The pedagogy of the educational institutions should be designed in such a way that the assignment of role playing, reasoning out etc. to bring out the hidden potentialities untapped so far.

In order to support the above mentioned view the following findings adds weight age $\%$ of students opined that the employability skills to be embedded from the school level

\section{1 \% OF STUDENTS OPINION TO BECOME THE FUTURE ENTREPRENEURS}

\begin{tabular}{|l|l|l|l|c|}
\hline $\begin{array}{l}\text { Total } \\
\text { No. of } \\
\text { Students }\end{array}$ & Agree & $\begin{array}{l}\text { Somewhat } \\
\text { Agree }\end{array}$ & $\begin{array}{l}\text { Strongly } \\
\text { Agree }\end{array}$ & Disagree \\
\hline $30(\mathrm{UG})$ & 47 & nil & 47 & 6 \\
\hline $20(\mathrm{PG})$ & 37 & 27 & 36 & nil \\
\hline
\end{tabular}

The response of the UG(outgoing students ) and PG(completed the first year) expresses their view that the pedagogy of the educational institutions should be designed in such a way to deliver the message of employability skills. Almost all the students cast their votes in favour and none of the PG students has disagreed for this idea except a meager percentage from the UG level.

\subsubsection{Testimonial message 1}

To kindle the aspirations of the young minds who are going to be the pillars of support in upholding this nation by their contribution in various fields, let us hearken to their voices in the following texts.

"Right from my childhood till date I always had excellent relationship with my teachers" - ArunavaDas Chaudhary Vice President, Investments \& Research AL Tameer Real Estate \& Investment Company[5]

.He emphasis the feature that there should be the good rapport between the teacher and the student and thus reveals out the secret for his success.

\subsubsection{Testimonial message 2}

Mr. Vrajendra Rana, Project Manager- R \& CM IBM India in His alumina speech in the IIPM Alumina Magazine says that 'It is the schooling and upbringing that makes you what you are' he adds, grooming at home which is important, there is no dictionary or a book to teach how to groom your child, but the parents need to understand they have to trust $\&$ build confidence in their child.[6]

\subsubsection{Motivation a mighty weapon in the hands of parents}

The parents to be given awareness to implant the seeds of interest in the young minds to reap out the benefits in the later stage. Though we cannot not expect them to make children to visualize the entire scenario, but they (parents) could play a significant role in explaining the importance, because the psychological researches has proven that a child of the affectionate parents will come out in flying colours in their near futures, whereas the love and affection and the oneness of mind are the rare jewels found missing in many of the families which is the warning bell to our nation.

\subsubsection{Testimomial Message 3}

A lot of leadership skills you learn at home. There is no leadership without a context, says Professor of Leadership Development and organizational change (Manfred Kets de vries in his case study on British entrepreneurial businessman Richard Branson whose parents were interviewed for the research)[7] So to inculcate the skills and to make their children to put on the armor (skills) to withstand anything under the sun, of course this preparatory process starts at home by the warmth touch of the loved ones

Nowadays the parents thrust their interest and views in selecting a course which is a wrong method at the right time. The parent's interests are very much influenced by the suggestions of their neighbors. If the education is forcibly injected to the students it will not last for ever and further the disliking of the course makes him to get boredom in bringing out his talents. In this context, it is the immense role of the parents to create a healthy mental atmosphere in bringing up the child to face the growing requirement for transnational resources. The role to be played by the parents is not binary, both the father and the mother they have their respective roles to mould up a child in terms of quality he/she possess and cannot be narrowed down to a particular area or a concept. 


\section{The entry of Corporate houses in the educational institutions for the successful exit of the students}

The corporate world continue to expand globally sponsors the employees for many executive programmes \& training to probe into the matter of finding out the source from which they could pick up the impeccable gems to adorn their official chambers.

Where the grooming process starts? Is it in the organization? Or in B- Schools? No it could very well be started from the educational institution which forms as the very source to pass on the quality education otherwise known as the skill needed to place themselves (students) in the corporate world. So now the corporate sector in search of employees has to define its geographical limits inside the horizon of the educational institutions. Again it should not be misinterpreted as campus interview. Instead of selecting a person who is at the verge of completion or the victory stand, it has to focus its attention from the starting point where the young minds with their exhibited innocence and the hidden fear of being exposed to the college life, waits for the education by looking at the prestigious institutions.

The above discussed concepts many times ends up with the disliking of the corporate magnates with the maneuver questions - Is this my field to reap out the efficient employees? or Is it the correct time to reap out the manifold yields? Securing a degree, while virtually undergoing corporate issues in which he is going to be placed (If they prove themselves satisfactory) makes the students to strike out the balance between educational curriculum and the practical aspects of the syllabi which would break out the ice of being a new entrant

Ms. Aparajita Verma an Engineering student, expresses her view in the Magazine Smart Manager Case Contest- Even you have a noble purpose and excellent skills and resources, but you don't have a method to use them to your advantage, you will end up in scattering all your energy and it will result in loss, this text well suits to our current discussion. [8]

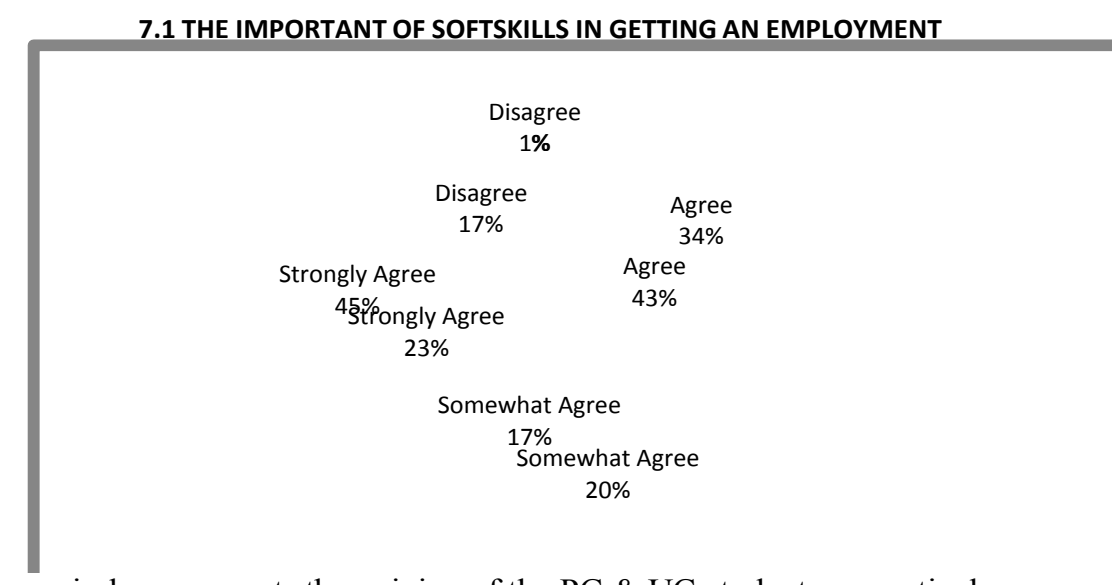

.Note: Outer \& Inner circles represents the opinion of the PG \& UG students respectively

Majority of the students have given their opinion that the soft skills are needed to be sharpened than the academic knowledge comparatively. This information shows their longing in acquiring these skills.

The industrial sectors could take up the task under one blanket of social responsibility. One cannot predispose the fact that early risk would fetch a longstanding benefit. The rationale behind this concept may sound economically incorrect, but this would be the widespread net to have cost -effectiveness. Altogether one cannot say that all the travelers (HRs) would get their share of good fortune, there might be the changes of misfortune too but anyway it will not outweigh the measure of success. The hands on approach between the educational institutions and the corporate world could bring career education curriculum. Points to be made clear is, corporate sector must be ready to be bound itself with the educational institution in nurturing the quality of education (from the initial stage and taking up the steps as much as possible) to disseminate corporate office needed skills to the youngsters without any reservation to some young chaps. In order to avoid a great degradation in the quality of education, again, choices not to be given only to the selected institutions to pick out the creamy layers of the society. Sometimes the road less traveled by or not chosen by many would take us to a green pasture. Surprisingly any person from any institution can be exalted to any position. "A Black cow can take the Green grass and can also give White milk" 
VIII. The role of Incubation Centre in enhancing the employment skills

Leadership Today: An inward journey by Shellie Karabell, journal Indian Management (June2012) metaphorically pictures the need of the job skills-"Technology means job skills needed to be upgraded continually while business can be eclipsed practically overnight."[9]

Mr. H. P. Kumar, Chairman and Managing Director of the National Small Industries Corporation (NSIC) while mentioning the importance of incubation, he clearly makes the mention that the unemployed persons who are vulnerable due to lack of higher education and sound financial means- for them to create employment opportunities and for capacity building (Skill Building)-National Small Industries Corporation (NSIC) has started a programme that provides integrated support through rapid incubation.[10]

To underscore the points of him, lack of financial means a reason for the vulnerability. The present study revealed the actuality that many students have the eagerness to enroll themselves with the B-schools but their hands are chained up, their eyes are closed up and their mouths are shut up for just one reason i.e Money

\subsection{THE \% OF STUDENTS AGREES THAT MONEY IS THE CONSTRAINT FOR THEM TO} PURSUE THE SKILLS

\begin{tabular}{|c|l|l|l|l|}
\hline $\begin{array}{l}\text { Total No. of } \\
\text { Students }\end{array}$ & Agree & $\begin{array}{l}\text { Somewhat } \\
\text { Agree }\end{array}$ & $\begin{array}{l}\text { Strongly } \\
\text { Agree }\end{array}$ & Disagree \\
\hline $30(\mathrm{UG})$ & 43 & 20 & 27 & 10 \\
\hline $20(\mathrm{PG})$ & 35 & 30 & 35 & nil \\
\hline
\end{tabular}

It is inferred from the above table, majority of the students take their steps back by looking at the financial commitments of their family members. Even though have their zeal and passion.

Many incubation centers provides complete assistance right from the start- on the job training, preparation of project reports, market surveys, raw material assistance, identification and procurement of plant and machinery, credit support, testing and handing over the project etc.

Though the aforesaid training is manifested in different angles, put together we address this as the skills needed to sustain in an organization and to sustain the organization too. Almost all IIms and IIts have their independent incubation centers and the government provides financial assistance to universities to set up incubators. The government provides grants to the incubators in order to be provided to its incubate companies. This incubation centers can also have the visits to the educational institutions, its warmth could be very well started in the colleges and its gentle touch in the higher secondary level (according to the course and to certain extent).

\section{Conclusion}

To conclude the inexorable topic, If the following steps are properly carried out by the educational institutions, or the interested corporate sectors where they have the tie-ups and by the government undeniably, would elevate the person who find himself on the tiny stand to an uphill task.

- Preparing the students minds to receive the seed of employability skills as it is and also it is sown.

- Moulding them up ready to get acquainted with any environment.

- Making them to study the ground (field) where they have to lay their foot.

- Understanding the human psychology of the human resources ( behavioural pattern-how to get along with the people)

- Injecting in their personality the virtual values -Social commitment, uprightness, Integrity in their dealings.

- Giving them the assignment of finding out the success of the great achievers in the world, their hardships and the path they undergone to reach the pinnacle of success.

- Along with above points the skills which is essentially the soft skills, and economically the technical skills (if needed) to be taught.

Skill building concept is not an Himalayan task, but a stone to be embedded in the crown and the gown of convocation.

CULT The IIPM Alumini Magazine, July 2012 Vol1 Issue 9

[2] Rural Employment Strategies for India/MSS Research Dt 12/13/12

[3] The Smart Manager May-June, Volume 11, Issue 3

[4] Turning Eastside Kids Into Westside Kids: Employability Skills in the Britist Columbia Career and Personal Planning Curriculum. Journal of Educational Thought Vol. 43, No.2, 2009,151-169.

[5] The IIPM Alumini Magazine, July 2012, Volume 1 Issue-9.

[6] The IIPM Alumini Magazine, July 2012, Volume 1 Issue-9

[7] Indian Management, The Journal of All India Management Association Volume 51 Issue 6 June 2012.

[8] The Smart Manager, May-June 2012, Volum4e 11, Issue 3.

[9] Indian Management, The Journal of All India Management Association Volume 51 Issue 6 June 2012

[10] Small Medium Entrepreneur Magazine, Volume 1 No.2, June - July 2012. 